\title{
Reversible corticospinal tract hyperintensities in neurologic Lyme disease
}
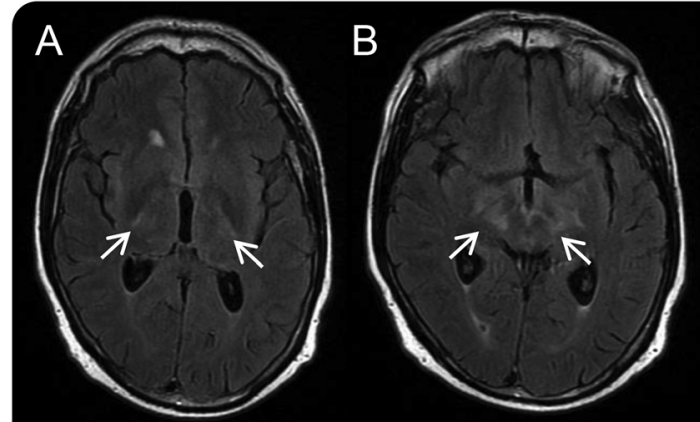

C

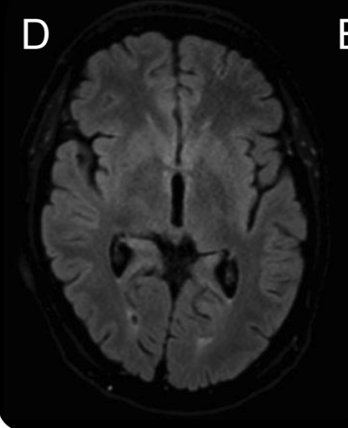

E

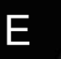

$(A, B, D, E)$ Axial and (C, F) coronal fluid-attenuated inversion recovery (FLAIR) MRI. (A) Bilateral corticospinal tract hyperintensities (white arrows): internal capsules in FLAIR axial and coronal (C) and mesencephalon (B). (D-F) Ten-month follow-up MRI shows total regression of FLAIR hyperintensities.

A 60-year-old man presented with an ataxic and spastic gait with paraparesis, having reported a tick bite. Brain MRI depicted bilateral corticospinal tract hyperintensities (figure). He had a mild lymphocytic meningitis (12 leukocytes $/ \mathrm{mm}^{3}$, proteinorachia $1.48 \mathrm{~g} / \mathrm{L}$ ). ELISA was positive for Lyme disease in serum (immunoglobulin $\mathrm{G}$ [IgG] $176 \mathrm{UI}$ and immunoglobulin M <4 UI) and CSF (IgG $300 \mathrm{UI}$ ) with an intrathecal synthesis (index of $\mathrm{CSF} /$ serum-specific antibodies equal to 16 using ELISA [normal value $<1.5]$ ]). Western blot was positive for Lyme-specific antibodies in serum $(18,22,32,41,60$, and $75 \mathrm{kDa})$ and CSF (41 and $60 \mathrm{kDa})$. Syphilis serology was negative. After treatment (IV ceftriaxone $2 \mathrm{~g}$ daily for 4 weeks), gait improved and brain MRI was normal. This MRI pattern has been previously reported in amyotrophic lateral sclerosis ${ }^{1}$ and in metabolic diseases (Krabbe disease, ${ }^{2} \mathrm{X}$-linked adrenoleukodystrophy, cerebrotendinous xanthomatosis) or infectious diseases (human T-cell lymphotropic virus 1).

Estelle Pruvost-Robieux, Jennifer Yeung, MD, Veronica Sudacevschi, MD, Yves Cordoliani, MD, Maxime De Malherbe, MD, Fernando Pico, $M D, P h D$

From Versailles Hospital (E.P.-R., J.Y., V.S., M.D.M., F.P.); and Parly 2 Clinic (Y.C.), Le Chesnay, France.

Author contributions: Estelle Pruvost-Robieux: study concept and design, analysis of data. Jennifer Yeung: acquisition of data. Veronica Sudacevschi: acquisition of data. Yves Cordoliani: acquisition of data, interpretation of data. Maxime de Malherbe: acquisition of data. Fernando Pico: critical revision of manuscript, study concept and design, analysis and interpretation of data.

Study funding: No targeted funding reported.

Disclosure: The authors report no disclosures relevant to the manuscript. Go to Neurology.org for full disclosures.

Correspondence to E. Pruvost-Robieux: estelle.pruvost@live.fr 
1. Pradhan S, Yadav R, Mishra VN, Aurangabadkar K, Sawlani V. Amyotrophic lateral sclerosis with predominant pyramidal signs: early diagnosis by magnetic resonance imaging. Magn Reson Imaging 2006;24:173-179.

2. Sehgal R, Sharma S, Sankhyan N, Kumar A, Gulati S. Selective corticospinal tract involvement in late-onset Krabbe disease. Neurology 2011;77:e20.

\section{Save These Dates for AAN CME Opportunities!}

Mark these dates on your calendar for exciting continuing education conferences by the American Academy of Neurology.Learn more at AAN.com/conferences.

\section{Fall Conference}

- October 14-16, 2016, Las Vegas, NV, at the Cosmopolitan of Las Vegas

\section{Complimentary CME and Self-assessment Resources: An Exclusive AAN Membership Benefit!}

Looking for ways to earn important CME credits in 2016? Look no further, because AAN membership provides FREE* access to the AAN's suite of online learning programs: NeuroSAE ${ }^{\circledR}$, NeuroLearn $^{\mathrm{SM}}$, and NeuroPI ${ }^{\mathrm{SM}}$. Access from virtually anywhere-home or office-to meet your CME needs, as well as take the necessary steps toward fulfilling your maintenance of certification (MOC) requirements, as mandated by the ABPN. Visit AAN.com/view/MOC today!

*Free access is limited to one course per program at a time.

\section{MACRA Changes How Neurologists Are Paid}

What Is MACRA, and Why Is It Necessary?

The Medicare Access and CHIP Reauthorization Act of 2015-MACRA-replaced the Medicare Sustainable Growth Rate formula for calculating physician payments. The rapidly rising costs of health care in the US are unsustainable. Changes in the health care system are essential and must happen now.

\section{How Will MACRA Affect Physician Payment?}

Our health care system is moving from "fee-for-service" payments to a wider array of "value-based" payment models that put the patient at the center of care by calling for the improvement of the quality, safety, and overall experience of patient care while demonstrating cost-effectiveness by providing care that is less expensive and delivers similar or improved clinical outcomes.

Learn more at $A A N$.com/view/MACRA. 


\section{Neurology}

\section{Reversible corticospinal tract hyperintensities in neurologic Lyme disease \\ Estelle Pruvost-Robieux, Jennifer Yeung, Veronica Sudacevschi, et al. \\ Neurology 2016;87;548-549 \\ DOI 10.1212/WNL.0000000000002913}

This information is current as of August 1, 2016

\section{Updated Information \& Services}

References

Subspecialty Collections

Permissions \& Licensing

Reprints including high resolution figures, can be found at: http://n.neurology.org/content/87/5/548.full

This article cites 2 articles, 1 of which you can access for free at: http://n.neurology.org/content/87/5/548.full\#ref-list-1

This article, along with others on similar topics, appears in the following collection(s):

Bacterial infections

http://n.neurology.org/cgi/collection/bacterial_infections MRI

http://n.neurology.org/cgi/collection/mri

Information about reproducing this article in parts (figures,tables) or in its entirety can be found online at:

http://www.neurology.org/about/about_the_journal\#permissions

Information about ordering reprints can be found online:

http://n.neurology.org/subscribers/advertise

Neurology ${ }^{\circledR}$ is the official journal of the American Academy of Neurology. Published continuously since 1951, it is now a weekly with 48 issues per year. Copyright (O 2016 American Academy of Neurology. All rights reserved. Print ISSN: 0028-3878. Online ISSN: 1526-632X.

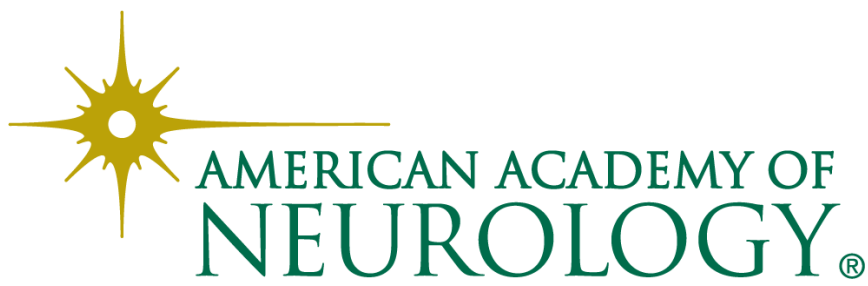

